\title{
LEONARD BACON
}

New England Reformer and Antislavery Moderate

\section{HUGH DAVIS}

Davis presents the first full treatment of the life and work of Leonard Bacon, the reformer, editor, church leader, and author who influenced northern Protestants' thinking for more than fifty years. By detailing

Bacon's vigorous efforts to connect his church and community to arenas of national scope, Davis offers new insights into the nineteenth-century Protestant ministry, the evangelical mentality, and the attempts of Bacon's contemporaries to address the moral and social issues of their time.

\section{PLAN AHEAD}

\author{
Spring Meeting \\ 28-30 April 2000 \\ Santa Fe, New Mexico
}

Proposals for papers and sessions are welcomed by the Program Committee. Send abstracts of papers and CVs of all participants to

$$
\begin{gathered}
\text { Professor Randi J. Walker } \\
\text { Pacific School of Religion } \\
1789 \text { Scenic Avenue } \\
\text { Berkeley, CA } 94709
\end{gathered}
$$

Deadline for submitting proposals: 15 September 1999 


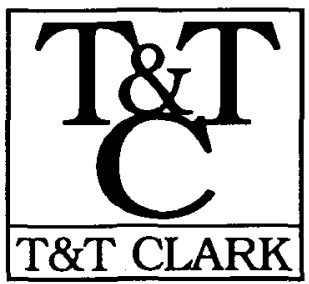

NEW

IN

CHURCH

HISTORY
A. C. Cheyne

STUDIES IN SCOTTISH CHURCH HISTORY

Explores the history of the churches of Scotland since the Reformation, focusing on its leaders, including Robert Rollock, Robert Leighton, William Carstares, Thomas Chalmers, John Tulloch, John Caird, Henry Drummond, John Baillie and Donald Baillie. Alec Cheyne illuminates how much change and diversity in thought, worship, government and culture these 400 years have witnessed.

Cloth 0-567-08644-5 352 pp \$49.95

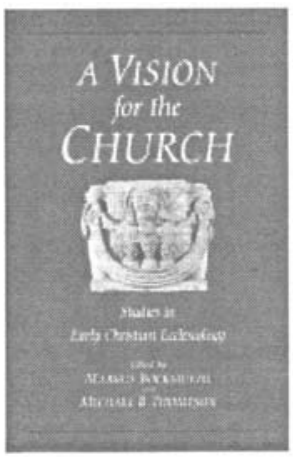

Markus

Bockmuehl and Michael B.

Thompson, editors

A VISION FOR THE CHURCH

Studies in Early Christian

Ecclesiology

This stimulating

collection of essays by an international group of New Testament experts examines how early Christians viewed the Church; its origins, purpose and relation to Jewish Scriptures and to Jesus Christ; its place in the world and in God's plan; and its community life and worship, both in theory and practice.

Paper 0-567-08579-4 262 pp $\$ 29.95$

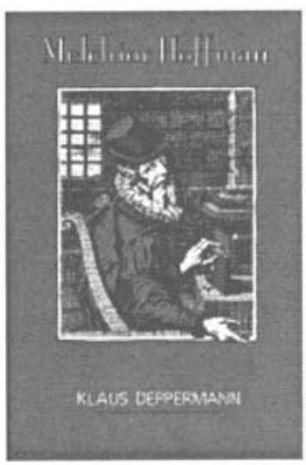

Klaus

Deppermann MELCHIOR HOFFMAN

Social Unrest and Apocalyptic

Visions in the Age of

\section{Reformation}

This comprehensive modern biography of Melchior Hoffman,

one of the most important figures in the "radical Reformation," traces not only his intellectual development but analyzes the various groups of his followers and relates his life and work closely to the social and political context of his time.

Paper 0-567-08654-2 440 pp \$34.95
Send for our complete catalogue

ORDER TOLL FREE

1-800-359-7340

FAX 1-703-661-1501

Use your VISA or MasterCard
ORDER BY MAIL

Add $\$ 5$ first book, $\$ 1$ ea. add. for S\&H

Make check payable and mail to:

T\&T Clark Publishers

Dept. CH

P.O. Box 605, Herndon, VA 20172 


\section{New Books from CUA PRESS}

\section{Controversial Concordats}

The Vatican's Relations with

Napoleon, Mussolini, and Hitler FRANK J. COPPA, Editor

Offers an engaging survey of the relationship of the Roman Catholic Church with three dictatorial figures. The authors trace the evolution of each of the concordats, and assess their contributions and their impact on the Church, the Catholic faith, and international relations.

$\$ 44.95$ cloth (0-8132-0908-0)

$\$ 24.95$ paper $(0-8132-0920-X)$

\section{War and Religion}

Catholics in the Churches of

Occupied Paris

VESNA DRAPAC

An illuminating study of Parisian Catholic life from the European Crisis of the late 1930 s to the end of Nazi Occupation in 1944. Drapac discusses the nature of Catholic loyalty to the Vichy regime and the range of religious responses to the ordeal.

\$74.95 cloth (0-8132-0903-X)

\section{Varieties of Ultramontanism JEFFREY VON ARX, Editor}

Explores the differing views of six ultramontane cardinals on papal authority. The cardinals examined are: Johannes von Geissel, Louis-Edouard Désiré Pie, Paul Cullen, Henry Edward Manning, Camillo Mazzella, S.J., and William Henry $O^{\prime}$ Connell. $\$ 34.95$ cloth (0-8132-0871-8) $\$ 19.95$ paper (0-8132-0872-6)

\section{Word, Church, and State}

Tyndale Quincentenary Essays JOHN T. DAY, ERIC LUND \& ANNE M. O'DONNELL, Eds. This collection of essays - based on papers from the Washington International Conference celebrating the 500th anniversary of Tyndale's birth - contains cuttingedge work by some of the world's most established scholars currently working on Tyndale. The essays makes fresh linguistic, historical, and theological contributions. $\$ 39.95$ cloth (0-8132-0902-1)

\section{The History of Philosophy in Colonial Mexico MAURICIO BEUCHOT, O.P.}

Presents a critical study of the wealth of philosophical activity in Mexico from 1500 until 1800. Beuchot traces how ideas developed and how philosophers influenced each other. \$64.95 cloth (0-8132-0906-4)

OF RELATED INTEREST

\section{Hesburgh: A Biography MICHAEL O'BRIEN}

An compelling biography of one of the greatest Catholic leaders in American history. $O^{\prime}$ Brien chronicles Father Theodore Hesburgh's career as Notre Dame president, political appointee, U.S. Civil Rights Commission chairman, and priest. $\$ 34.95$ cloth (0-8132-0921-8)

\section{THE CATHOLIC UNIVERSITY OF AMERICA PRESS}




\section{Turn to TENNESSEE for Provocative Reading!}

\section{Building a Protestant Left} CHRISTIANITY AND CRISIS MACAZINE, 1941-1993

Mark Hulsether

"A rich, nuanced history of the rise and fall of the most influential Protestant journal of the post-World War II period, Hulsether's book fills a major hole in the cultural historiography of postwar liberalism."-Doug McAdam, author of Freedom Summer

Feb., 416 pages, ISBN $1-52733-022-8, \$ 38.00$

\section{Fire in His Heart}

BISHOP BENJAMIN TUCKER TANNER

AND THE A.M.E. CHURCH

\section{William Seraile}

"A very well-researched, well-organized biography of Benjamin Tucker Tanner, one of the major leaders of the African Methodist Episcopal Church, who made significant intellectual and pastoral contributions in his roles as minister, editor, and bishop."-Sandy Dwayne Martin, University of Georgia

256 pages, illus., ISBN 1-57233-027-9, $\$ 32.50$

\section{The Self and the Sacred} CONVERSION AND AUTOBIOGRAPHY IN EARLY AMERICAN PROTESTANTISM Rodger M. Payne

Examining the conversion narratives and spiritual autobiographies that proliferated in early America, Rodger Payne focuses on what they reveal about notions of selfhood.

136 pages, ISBN 1-57233-015-5, $\$ 27.00$

\section{Declarations of}

\section{Independency in}

\section{Eighteenth-Century}

\section{American Autobiography}

Susan Clair Imbarrato

This book examines the changes in the

American autobiographical voice as it speaks through the transition from a colonial society to an independent republic. Conversion narratives are among the genres it considers. 192 pages, ISBN 1-57233-012-0, $\$ 32.50$

Shipping \& handling: $\$ 3.50$ for first book; $\$ .75$ for each additional book.

\section{Presbyterian Pluralism}

COMPETITION IN A PROTESTANT HOUSE

William I. Weston

"Weston's rich analysis of two earlier Presbyterian crises is replete with implications for the 'culture wars' which grip mainline Protestantism in these latter days of the twentieth century. . . . Weston provides a persuasive and welcome note of balance and hope as we head into an increasingly shrill and debilitating debate."-Donald A. Luidens, Hope College

208 pages, illus., ISBN 0-87049-982-3, \$30.00

\section{Reverend Joseph Tarkington,} Methodist Circuit Rider

FROM FRONTIER EVANGELISM

TO REFINED RELIGION

David L. Kimbrough

Tracing the rise in fortunes of a Methodist minister in nineteenth-century Indiana, this book presents a vivid picture of the political, social, and religious culture of that time and place.

240 pages, illus., ISBN 0-87049-979-3, $\$ 35.00$

\section{Wise as Serpents, Innocent as Doves}

AMERICAN MENNONITES

ENGAGE WASHINGTON

\section{Keith Graber Miller}

This book examines the activities of the Washington office that was opened in 1968 by the Mennonite Central Committee for monitoring the actions of the federal government. The author shows how the church's traditions of pacifism, humility, and service have informed the nature of its work in the nation's capital. 328 pages, illus., ISBN 0-87049-936-X, $\$ 36.00$

\section{Evangelicals and Politics in Antebellum America}

Richard J. Carwardine

"This superbly researched and expertly written book makes a signal contribution to American history as well as to the history of religion."Mark Noll, Christianity Today

512 pages, ISBN 0-87049-974-2, $\$ 25.00 \mathrm{pa}$

UT Press Online: http://sunsite.utk.edu/utpress 


\section{New in paperback}

\section{The Ladies of Zamora}

\section{PETER LINEHAN}

"[Linehan] paints a vivid and compelling picture of a community whose members found themselves caught up in larger conflicts of authority within the Church and between Church and State.... A fine example of the way in which study of the local and the particular opens out on to the wider perspectives of Castilian history and the problems a Church as a whole faced with the rise of the mendicant Orders."

—Colin Thompson, Times Literary Supplement 208 pages 6 illustrations $\$ 18.95$ paper

For sale in the U.S. and Canado only

\section{Charlotte von Kirschbaum and Karl Barth}

A Study in Biography and the History of Theology

\section{SUZANNE SELINGER}

The first concentrated study of the longterm collaboration of the towering theologian Karl Barth and his secretary and theological assistant, Charlotte von Kirschbaum.

208 pages $\$ 19.95$ paper

Penn State Studies in Lived Religious Experience

\section{Apparitions of the Madonna at Oliveto Citra}

Local Visions and Cosmic Drama

PAOLO APOLITO

Translated by William A. Christian, Jr.

An account of how modern reports of appearances of the Virgin Mary turned the Italian village of Oliveto

Citra into a pilgrimage site.

288 pages $\$ 49.50$ cloth

\section{Margherita of Cortona and the Lorenzetti}

Sienese Art and the Cult of a Holy Woman in Medieval Tuscany

\section{JOANNA CANNON AND ANDRÉ VAUCHEZ}

"A model of how art-historical sources should be used for the history of religious sentiment."

-David d'Avray, University College, London 428 pages $204 \mathrm{~b} \& \mathrm{w} / 26$ color illus. $\$ 80.00$ cloth

\section{MAGIC IN HISTORY SERIES}

\section{Forbidden Rites}

A Necromancer's Manual of the Fifteenth

\section{Century}

\section{RICHARD KIECKHEFER}

"Forbidden Rites is the best book on magic in the late Middle Ages and a great introduction to the problematic relations of magic and religion in general."

-H. C. Erik Midelfort,

392 pages $\$ 19.95$ paper University of Virginia

\section{Conjuring Spirits}

Texts and Traditions of Late Medieval Ritual Magic

\section{EDITED BY CLAIRE FANGER}

Conjuring Spirits contains both general surveys and analyses of magical texts and manuscripts by distinguished scholars in a variety of disciplines.

224 pages 30 illustrations $\$ 19.95$ paper

\section{Ritual Magic}

\section{ELIZABETH BUTLER}

"Butler's survey is the classic scholarly treatment of a tradition that extends from the later Middle Ages into the early Modern era: the tradition of texts that teach ceremonial magicians how to conjure good or evil spirits." - Richard Kieckhefer

336 pages $\$ 19.95$ paper

\section{The Fortunes of Faust \\ ELIZABETH BUTLER}

"The skill and precision with which Butler delineates the phases of the Faust tradition is no less impressive than the elegant magnanimity which she displays in judging the great as well as that host of minor poets whose labors equally testify to the inexhaustible fascination of 'the conflict between religion and rationalism as to the ultimate fate of the Faustian spirit, the desire for infinite knowledge." - Yale Review 384 pages $\$ 19.95$ paper

\section{All books in the series are for sale in the U.S. and} Canada only

\section{Penn State University Press}

USB 1, Suite C - University Park, PA 16802

Orders: 800-326-9180

Toll free fax: 877-PSU-BOOK

http://www.psu.edu/psupress 
UNITED STATES POSTAL SERVICETM

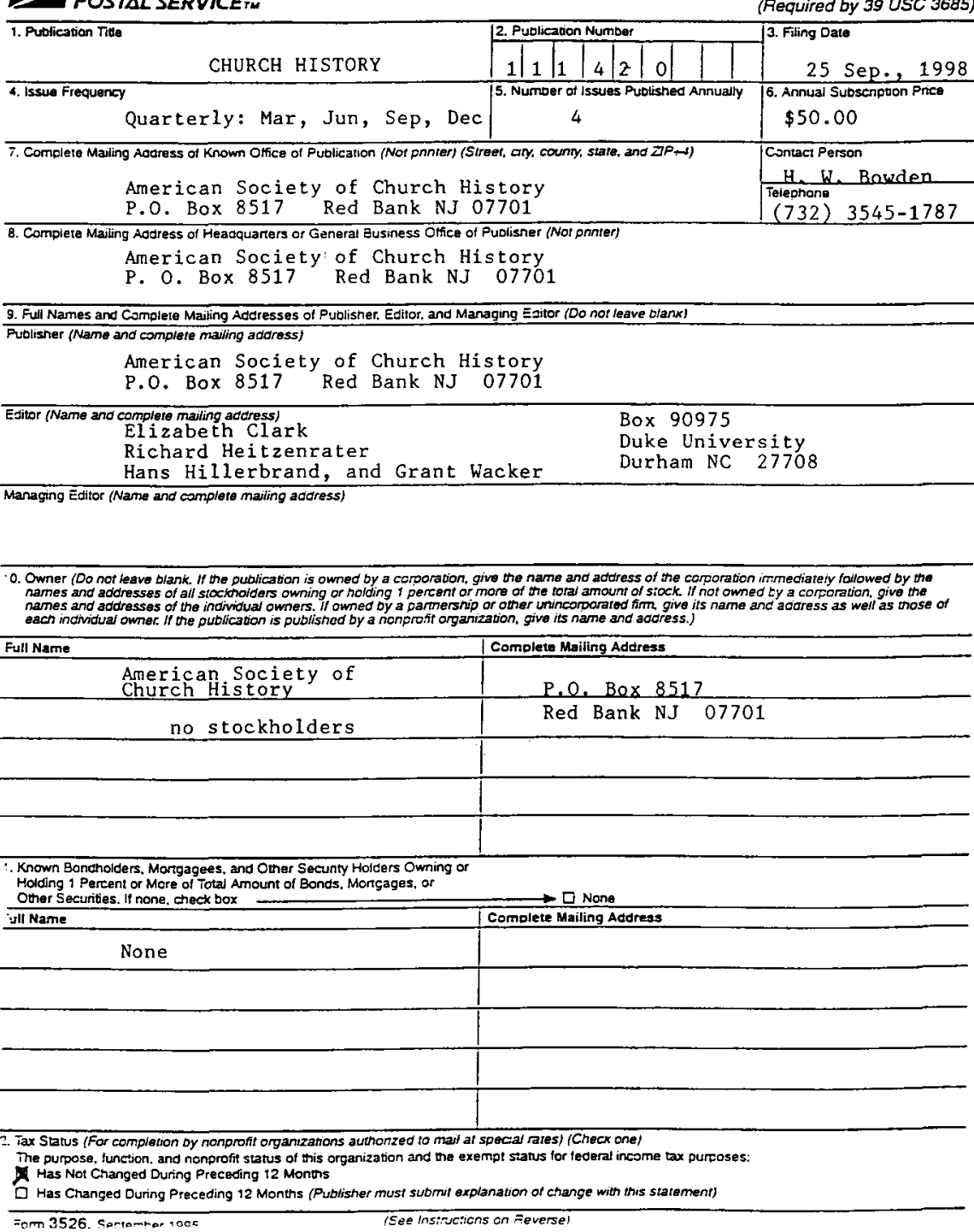

Statement of Ownership, Management, and Circulation (Required by 39 USC 3685) 


\begin{tabular}{|c|c|c|c|}
\hline \multirow{2}{*}{\multicolumn{2}{|c|}{$\begin{array}{l}\text { 13. Publication Title } \\
\text { CHURCH HISTORY }\end{array}$}} & \multicolumn{2}{|c|}{ 14. Issug Date tor Circulation Data Below } \\
\hline & & \multicolumn{2}{|c|}{25 September 1998} \\
\hline 15. & Extant and Noture of Circulation & $\begin{array}{l}\text { Avergge No. Copies Esch lasus } \\
\text { During Preceding } 12 \text { Montens } \\
\end{array}$ & $\begin{array}{l}\text { Actual Mo. Copies of Single lssut } \\
\text { Publighed Newrest to Filing Date }\end{array}$ \\
\hline \multicolumn{2}{|c|}{ a Total Number of Copies (Net press run) } & 3330 & 3330 \\
\hline \multirow{2}{*}{$\begin{array}{l}\text { b. Paid anct/or } \\
\text { Requested } \\
\text { Circulation }\end{array}$} & $\begin{array}{l}\text { (1) Sales Through Dealers and Carriers, Street Vendors, } \\
\text { and Counter Sales (Not mailed) }\end{array}$ & None & None \\
\hline & $\begin{array}{l}\text { (2) Paid or Requested Mail Subscnpoions (Incudus } \\
\text { advertiser's proof copies and exchange copies) }\end{array}$ & 2975 & 2975 \\
\hline \multicolumn{2}{|c|}{$\begin{array}{l}\text { c. Total Paid and/or Pequested Cireulation } \\
\text { (Sum of } 150(1) \text { and } 150(2))\end{array}$} & 2975 & 2975 \\
\hline \multicolumn{2}{|c|}{$\begin{array}{l}\text { A. Free Distribution by Mail } \\
\text { (Samples. complimentany, and orher tree) }\end{array}$} & 255 & 255 \\
\hline \multicolumn{2}{|c|}{ e. Free Distribution Outside the Mail (Camiers or other means) } & None & None \\
\hline \multicolumn{2}{|c|}{ t. Total Free Distribution (Sum of $15 d$ and $15 e$ ) } & 255 & 255 \\
\hline \multicolumn{2}{|c|}{ 9. Total Oistribution (Sum of $1 \leq c$ and 15 ) } & 3230 & 3230 \\
\hline \multirow{2}{*}{$\begin{array}{l}\text { h. Copies not } \\
\text { Distributad }\end{array}$} & (1) Ofice Use, Lettovers. Spoiled & 100 & 100 \\
\hline & (2) Festurns trom News Aggents & None & None \\
\hline \multicolumn{2}{|c|}{ i. Total (Sum of 15g. 15h(1), and 15n(2)) } & 3230 & 3230 \\
\hline \multicolumn{2}{|c|}{$\begin{array}{l}\text { Percent Paid andror Requested Circulation } \\
(15 c / 15 g \times 100)\end{array}$} & 100 & 100 \\
\hline \multicolumn{4}{|c|}{$\begin{array}{l}\text { 16. Publication of Statement of Ownersnip } \\
\text { Putlication required, Will be printed in the Dec } 1998 \text { issue of this publication. } \\
\text { Publication not required. }\end{array}$} \\
\hline \multicolumn{3}{|c|}{ 17. Signaturgapo Tite of Editor. Pyblisher, Eusigess Manager, owner } & 25 Sep 1998 \\
\hline
\end{tabular}

\section{Instructions to Publishers}

1. Complete and file one copy of this form with your postnaster annually on or belore October 1. Keep a copy of the completed form for your records.

2. In cases where the stockholder or secunity holder is a trustee, include in items 10 and 19 the name of the person or corporation for whom the trustee is acting. Also include the names and addresses of individuals who are stockhoiders who own or hold 1 percent or more of the total amount of bonds, mortgages, or other securities of the publishing comoration. In item 11 , if none. check the box. Use blank sheets if more space is required.

3. Be sure to fumish all circulation information called for in item 15. Free circulation must be shown in items $15 d$, e, and f.

4. If the publication had second-class authcrization as a general or requester publication, this Statement of Ownership, Manacement, and Clreulation must be published; it must be printed in any issue in Cctoter or, if the publication is not published during Oetober, the first issue printed atter October.

5. In itern 16, indicate the dase of the issue in which this Statement of Ownership will be published.

6. Itern 17 must be signed.

Failure to file or publish a statement of ownership may lead to suspension of second-class authorization. 
Church History: Studies in Christianity and Culture is published four times per year (March, June, September, and December) by the American Society of Church History. Membership dues for individuals are $\$ 40$ per year for regular membership, $\$ 20$ per year for retired persons who previously held regular membership for at least five years; and free for two years for graduate students with the approval of a professor who is a member of the Society (after two years, graduate students pay $\$ 20$ annually until graduation). Institutional subscriptions are $\$ 50$ per year. Foreign postage is an additional $\$ 10$ per year. Single issues are $\$ 15$. Please make remittances payable to "American Society of Church History."

Office of the secretary-treasurer: American Society of Church History, P.O. Box 8517, Red Bank, NJ 07701-8517.

Subscription applications, renewals, changes of address, claims for missing numbers, orders for single copies of current or back issues, and requests for permission to quote should be sent to the secretary-treasurer. Claims for missing numbers will be honored without charge if made within two months of the regular month of publication.

Microfilm reproductions of The American Society of Church History Papers, series I and II, and of Church History, volumes 1-17 (1932-48), are available from the ATLA Preservation Board. Orders for these reproductions as well as inquiries about microfilm portions and photocopies should be sent to 1118 East 54th Place, Chicago, IL 60615.

Microfilm reproductions of Church History starting with volume 18 (1949) are available to subscribers and members of the Society from University Microfilms, 300 North Zeeb Road, Ann Arbor, MI 48106. The full text of Church History is also available in the electronic versions of the Humanities Index. Church History is indexed in Religion Index One: Periodicals, Index to Book Reviews in Religion, Religion Indexes: RIO/RIT/IBRR 1975- on CD-ROM, and ATLA Religion Database on CD-ROM, all published by the American Theological Library Association, 820 Church Street, Suite 400, Evanston, IL 60201-5613; (888) 665-ATLA; atla@atla.com; http:/ /atla.library.vanderbilt.edu/atla/ home.html.

The following indexes are available from the office of the secretary-treasurer: volumes 31-39 (1962-1970), volumes 40-49 (1971-1980), vols. 50-59 (1981-1990). Each index costs \$15. Book reviews are indexed or abstracted in Book Review Index, Historical Abstracts, and America: History and Life.

Editorial office: Church History, The Divinity School, Duke University, Box 90975, Durham, NC 27708-0975; (919) 660-3470; fax (919) 660-3473; church-history@duke.edu.

Send manuscripts, books for review, and requests about advertising to the editorial office. Manuscripts should run 6,000-11,000 words (or approximately 20-35 pages), not including endnotes, and should be printed double-spaced in 11- or 12-point font; endnotes must be printed double-spaced on separate pages following the text. The editors request (1) three copies of the manuscript (in order to protect the author's anonymity during the review process, the author's name should appear only on the title page of the essay); (2) three copies of a 200-word abstract (if Church History publishes the essay, the abstract may be printed above the first line of the text of the article and/or it may be included on the forthcoming Church History webpage); (3) a 31/2-inch diskette containing the manuscript and abstract (instead of sending a diskette, you may submit your manuscript and abstract by electronic mail). Further guidelines are available on request.

Church History is printed by the Science Press division of Mack Printing Group, Ephrata, Pennsylvania. Periodicals postage paid at Red Bank, New Jersey and additional mailing offices. Postmaster: Send address changes to American Society of Church History, P.O. Box 8517, Red Bank, NJ 07701.

\section{CHURCH History (ISSN 0009-6407)}

The opinions expressed in this journal represent the views only of the individual contributors; they do not necessarily reflect the views of the editors, Duke University, or the American Society of Church History. Advertising in Church History does not necessarily imply endorsement. 


\section{CONTENTS}

643 Calvin: A Prophet without a Prophecy Max Engammare

662 Augustine and the Amerindian in Seventeenth-Century New France Peter A. Goddard

682 Thomas Jefferson, Religious Freedom, and the Supreme Court

Edwin S. Gaustad

695 Revivals and Revolution: Historiographic Turns since Alan Heimert's Religion and the American Mind Philip Goff

722 The Rise of Southern Gospel Music James R. Goff Jr.

745 Books 